\title{
Reflections
}

\section{Is Rationalism Possible in the Muslim World?}

\author{
M. Umer Chapra
}

\begin{abstract}
This article looks at the rationalist movement in the Muslim world in the earlier centuries of Islam and discusses the reasons for its initial success and later setback. The article then discusses the implications of this setback for the revival of Islam and the ability of Muslim societies to meet successfully the challenges that they face in modern times.
\end{abstract}

The revival of Islam in the Muslim world raises a number of questions. One of these is whether this would lead to a conflict between reason and revelation and a change in the epistemology of knowledge in the same way as it did in the West, given the dominant influence of the West on the rest of the world, including Muslim countries. If such a conflict does arise, then the second question is whether it is possible for Islamic revival and rationalism to go hand in hand. The questions may be answered more comfortably if we look at Islamic history and see whether such a conflict did take place in the past and examine the reasons for and the implications of this conflict.

\section{The Rationalist Movement in the Muslim World}

The Rationalist movement or the Enlightenment arose in the Muslim world in the second century A.H. (eighth century C.E.), several centuries before it did in the West. Because of this the Muslim world was able to make path-breaking contributions to mathematics, physics, chemistry, astronomy, biology, medicine, and philosophy and to occupy the top place in these fields over a period of almost four centuries, from the middle of the eighth century to the middle of the twelfth century. ${ }^{1}$ Even after losing its

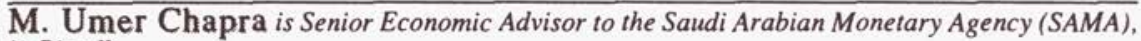
in Riyadh. 
dominance, it continued to make substantial contributions for at least two more centuries. However, while these contributions were being made, a serious conflict was going on simultaneously, not between science and revelation, but rather between revelation and philosophical speculation. The contention of this article is that one of the major factors, though not the only one, that led to the intellectual decline of the Muslim world was not so much the use of reason by the rationalists to discuss subjects which were transcendental and beyond the scope of reason, but rather their effort to impose some of their unacceptable views forcibly on an unwilling orthodoxy with the help of the coercive power of a political authority which did not enjoy the confidence of the people because of its political illegitimacy and the luxurious lifestyle of the leaders, in sharp contrast with Islamic teachings.

The rationalists consisted at that time of two groups of scholars having different intellectual backgrounds. These were the Mu'tazilites and the falasifa (philosophers; singular faylasuf). The Mu'tazilites $^{2}$ were basically religious scholars and not philosophers. They were, however, well-versed in philosophy and the physical sciences and wished to provide convincing rational arguments for religious beliefs and practices, in contrast with the extreme conservatives who would like people to accept these on the basis of blind faith. The rationalist approach had become necessary because of the rapid spread of Islam in territories previously under the influence of the materially more advanced and intellectually more sophisticated Sasanian and Byzantine civilizations. Without the adoption of such an approach, it may have been difficult to gain converts or even to save the common man from the adverse influence of heretics or zanadiq (singular, zindiq). The rationalists also tried to determine the nature and causes of the various phenomena in human life and the universe around them. Here their objective was to show that God does not operate in an arbitrary manner. He is rather systematic and methodical and operates on the basis of certain principles, which it is possible for human beings to discover. They were thereby trying to lay down indirectly a solid foundation for science within the religious paradigm.

To help them in this commendable task, they developed a systematic method of logical reasoning called ilm al-kalam. ${ }^{3}$ Those who employed this method were called mutakallimun, which literally means "reasoners." This method was original to the Muslims and, as Gardet has put it, was "certainly not an Arab adaptation of Mazdean or Christian theology." ${ }^{4}$ In 
essence there was little difference between the mutakallimun and the Mutazilites, and the two terms were sometimes used synonymously. They attracted scholars from all different shades of the Muslim spectrum. While some of them like Ja'far ibn al-Bishr (d. 226/841) and Abu Musa al-Murdar (d. 226/841) were renowned for their piety, others had the reputation of being lax in their religious observances. ${ }^{5}$

The falasifa, influenced by Greek philosophy, were primarily intellectuals and not religious scholars. ${ }^{6}$ Because of the close relationship between philosophy and science in those days, most of the philosophers were also well-recognized authorities of their time in sciences like mathematics, physics, chemistry, astronomy, and medicine. They also performed experiments to the extent they could, in keeping with the general practice of Muslim scholars in those days. They generally received government patronage and made substantial contributions to the development of these sciences. Moreover, since knowledge was not yet compartmentalized in those days, they were also quite well-versed in the religious sciences, and some of them, like Ibn Rushd (Averroes, d. 595/1198), were even considered authorities in these. While the extremists among them like Ibn alRawandi (d. 250/864) and Abu Bakr al-Razi (Rhazes, d. 313/925) held views that conflicted with fundamental Islamic beliefs, most of them, including al-Kindi (d. 252/866), al-Farabi (d. 339/950), Ibn Sina (Avicenna, d. 428/1037), and Ibn Rushd (d. 595/1198), were relatively moderate. They did not find any incompatibility between reason and revelation. In fact, they tried to show the harmony between the two and rationally argued in favor of revelation and prophethood, the hereafter, and other Islamic beliefs and practices. They quoted profusely from the Qur'an and the Sunnah to support their views.

The free and rational discussion of Islamic beliefs and practices raised a lively and sophisticated intellectual debate on a number of epistemological issues:

- What is the nature of God? Does He have a body with eyes, ears, hands, and legs? If not, how does He see, hear, hold, and move, and will it be possible for human beings to see Him? What are His attributes (sifat)? Are these attributes an integral part of His Being or separate from Him? Can reason help human beings know Him and His attributes, or are they totally dependent on revelation for this purpose? Does He know everything that will happen in the future, even what human beings are going to do? 
- If God is Eternal, is His creation also eternal? If not, was there a period when $\mathrm{He}$ was not a Creator? Is this conceivable?

- To what extent are human beings free or predestined? If their life is predestined, then would it be just for God to hold them accountable for their deeds and to reward or punish them?

- Is faith alone sufficient to be a believer or is it also necessary to reinforce it by deeds? Is a sinful Muslim a believer ( $\mathrm{mu}^{\prime} \mathrm{min}$ ), an unbeliever (kafir), or something in between (fasiq)?

- Will the resurrection of human beings in the hereafter be only of the soul or also of the body? If there will be bodily resurrection, will the body be the same as it is in this world or will it be different?

- If the Qur'an is a part of God's speech (kalam), then is it to be considered created and transitory like this world, or uncreated and eternal like other Divine attributes?

- To what extent is it possible for human beings to know what is right from what is wrong by means of reason, and to what extent is revelation necessary for this purpose? Is it conceivable that a just God would hold human beings accountable for their deeds without creating in them an innate ability to recognize right from wrong?

Hardly any of these questions had anything to do with science. The answers were bound to be speculative and could not have been given with precision. It was, therefore, not possible to have a single answer. There were shades of opinion and, therefore, neither the rationalists nor the conservatives constituted a homogenous whole. ${ }^{7}$ The real bone of contention was the extent to which reason and logic could help answer the above philosophical questions effectively. It seems, however, that the moderates among both the rationalists and the conservatives, who constituted a majority, appreciated the need for both reason and revelation in different degrees. However, it was the extremists on both sides who succeeded in getting greater attention and who, therefore, set the tone of the debate.

The moderate rationalists, who stressed a greater reliance on reason, developed a set of five axioms (al-usul al-khamsah) to help them argue their case more effectively. Two of the most important of these axioms were tawhid (unity) and 'adl (justice) of God, which are accepted by all Muslims without exception. ${ }^{8}$ There would be no point in relying on axioms that did not command a consensus. Differences nevertheless arose in the deduction of their implications.

With respect to tawhid, which is the most fundamental of all Islamic beliefs and stands for the absolute oneness and uniqueness of God, the gen- 
eral Muslim understanding is that, because of their limited capabilities and perceptions, human beings cannot comprehend Him fully. The Qur'an itself makes this crystal clear by saying that "there is nothing like Him (alQur'an, 42:11), and that human "eyes cannot encompass Him" (al-Qur'an, 6:103). ${ }^{9}$ Therefore, in keeping with a Qur'anic injunction (al-Qur'an, 3:7), the general Muslim attitude has been to accept on faith the unseen metaphysical realities which are beyond the reach of reason and sense perceptions and not to try to probe into them too deeply. This would be a fruitless exercise because, while the existence of God can be established through observation and logical reasoning, His nature cannot be understood fully except through His attributes (sifat) as revealed in the Qur'an and the Sunnah. The extreme rationalists, however, insisted that reason alone could enable human beings to know His nature. Their effort to do so got them embroiled into sterile and divisive controversies on a number of metaphysical questions like divine attributes, resurrection and life after death, angels, revelation and prophethood, eternity of the world, creation of the Qur'an, divine knowledge of particulars, and ability of human beings to see God in the hereafter. The extreme rationalists adopted hard-line positions which were in clear conflict with the Qur'an and the Sunnah and which the moderate rationalists had difficulty accepting.

With respect to the concept of ' $a d l$, the debate was more practical and relevant to the human condition even though it also raised a great deal of controversy. Some of the conclusions that the moderate rationalists derived were as follows:

- God subjects Himself to the same moral principles which He applies to human beings. He does only that which is just and morally right. It is inconceivable that He would do something that is unjust or morally wrong.

- Goodness or evil are innate in the nature of things themselves and not necessarily because God arbitrarily declares them to be so. It is, therefore, possible for human beings to recognize what is right or wrong through their own reasoning even though they need the help of revelation to guide them and to confirm their conclusions.

- Since God is just, there is absolutely no room for the concept of predestination. Human beings are the authors of their own deeds, good or evil; therefore, rewarding or punishing them would be a reflection of God's justice.

To a modern rationalist thinker there may be a great deal of appeal in some of these views. This appeal existed even in those days, and the initial objective, method, and concepts of the moderate rationalists did not gener- 
ate tension even among those members of the Muslim orthodoxy who did not accept the need for rational explanations for religious beliefs and practices. The differences of opinion that existed may have been resolved to a great extent over time in the light of the Qur'an and the Sunnah through rational debate. The question is, Why did this not take place?

\section{The Downfall of the Rationalists and the Move Toward Conservatism}

The extremists on both the conservative and the rationalist side generated a great deal of heat and changed the texture of the whole debate, creating an atmosphere of confrontation. On the conservative side, extreme conservatives like the Hashwiyyahs insisted that faith is based entirely on the Qur'an and the Sunnah and that there is absolutely no room for reason. In sharp contrast with this, extreme rationalists like Ibn al-Rawandi (d. 250/864) and Abu Bakr al-Razi (d. 313/925) ${ }^{10}$ insisted that reason and revelation were incompatible and that all matters, including right and wrong, should be judged by reason alone. They belittled all attempts at reconciling philosophy and religion and insisted on formulating a theology solely on the basis of reason, independent of revelation, approaching what became known later on in the West as natural theology. ${ }^{11}$ They tended to reject, just like the Western Enlightenment movement, all metaphysical truths that could not be established by means of reason and experience. Acceptance of their views would have pushed revelation into the background and made reason the sole determinant of faith instead of being a tool for its explanation and defense, as was the original aim of the Mu'tazilites.

Does this mean that there is no room for extreme views in human society? Not necessarily. Extreme views have sometimes made substantial contributions to human development and have later become generally accepted. However, social peace may in certain circumstances be served better if extremes are avoided at least in religious and social matters. Nevertheless, if such views do get put forward, then one would expect that people would give them a patient and tolerant hearing. If the extreme views are unable to establish their worthiness and gain general acceptance, they will die a natural death. Why then is it that extreme views created a problem in Muslim society? Was there a lack of tolerance?

There seems to be little evidence of this in the early Muslim society where tolerance generally prevailed and the debate between conservatives and rationalists progressed relatively freely and smoothly. Even a heretic 
like Ibn al-Rawandi (d. 250/864) received a patient hearing, and his arguments were logically refuted by several generations of eminent religious scholars. ${ }^{12}$ Given the spirit of the age, the prevailing intellectual controversies may perhaps have been resolved through free discussion, particularly because the differences of opinion between the moderates among the rationalists and the conservatives, who constituted a preponderant majority of the intellectuals, were not irreconcilable. What then was it that polarized the then Muslim society into two belligerent groups, when in the same society different fiqh schools were mutually tolerant and coexisted generally peacefully despite substantial differences of opinion?

The answer may perhaps lie in the use of force by a political authority which did not enjoy the trust of the people. Normally, in societies in which one group uses force to impose its views on another, the reaction of the suppressed group tends to be severe, particularly if the latter group happens to be in the majority. The Mu'tazilites exploited the political patronage and financial backing that they received from the government during a substantial part of the 'Abbasid dynasty (132/750 - 656/1258), and particularly during the reigns of Ma'mun al-Rashid (d. 218/833), al-Mu'tasim (d. 227/841), and al-Wathiq (d. 232/846) to impose their radical views forcefully on all. They became aggressive and intolerant, in clear violation of Islamic teachings, and introduced the mihnah or testing in the Muslim world. They went around and questioned people about their beliefs and threatened to punish those who held different views. "No faqih, muhaddith, mu'adhdhin or mu'allim [was left] untested." 13 Freedom of expression, which had been an important characteristic of Muslim society before this, almost disappeared. ${ }^{14}$ They jailed and tortured their opponents to impose the unacceptable views. "The prisons were full of those who had denied the mihnah." 15 Some of the prisoners, like Muhammad ibn Nuh (d. 218/833), Na'im ibn Hammad (d. 228/842), Yusuf al-Buwayti (d. 231/845), and Ahmad al-Khuza'i (d. 231/845), died in prison as a result of torture. ${ }^{16}$ Ahmad al-Khuza'i's head was "placed on public view in Baghdad as a grisly warning to potential nonconformists, while his cadaver stayed in Samarra', also on display."17 Even prominent jurists like Ahmad ibn Hanbal (d. 241/855), who were held in high esteem by the masses for their piety and scholarship, were not spared. He was flogged on the orders of alMu'tasim until he became unconscious. ${ }^{18}$ All this, because he was not willing to accept the Mu'tazilite view that the Qur'an was created. They even went to the extent of inscribing on the mosques of Fustat that "There is no 
god but God, the Lord of the created Qur'an," 19 thereby making the concept of "created Qur'an" an incontestable part of Islamic belief.

The question is, Why were the 'ulama so aggravated over an issue which may not appear to a number of people now to be of great significance? The use of force and persecution had the effect of creating bitterness and giving a hostile tone to an otherwise intellectual debate. It created suspicion among the "ulama about the motives of the government, making them feel, rightly or wrongly, that the state was trying to have a say in the definition of Islam. ${ }^{20}$ The concept of "created Qur'an" made them afraid that its acceptance would imply that the Qur'an was not eternally true and could be changed or overridden by the illegitimate and corrupt rulers. This they could not stand and steadfastly defended their position without being deterred by imprisonment or merciless flogging.

The mihnah and the resultant bitterness in the 'ulama against the government led to a continually rising unrest and discontent among the population, particularly in Baghdad. This made even the illegitimate political leadership of that time realize, though belatedly after the damage had been done, that the mihnah was unpopular and was not going to work. AlMutawakkil (d. 247/861), therefore, put an end to it in 234/849, roughly two years after his accession to the throne. Ahmad ibn Abi Du'ad, the Chief Qadi, who was perhaps the most instrumental in its harsh implementation, was disgraced, became paralyzed, and died unnoticed in 240/854.

The mihnah came to an end but left two permanent marks on Muslim society, one healthy and the other has been unhealthy. The healthy mark has been the distancing of the state from any role in the definition of Islam. The central teachings of Islam stand defined by the ijma' of the ummah in conformity with the Qur'an and the Sunnah. The unhealthy mark has been the alienation of a majority of the 'ulama' from philosophy and science. This has had the effect of driving them toward greater conservatism.

\section{Al-Ghazali and Ibn Rushd}

In spite of the use of force, the progress of rational debate on the subject continued between the rationalists and the conservatives, and the extreme rationalists gradually started losing ground. Their questionable views could not stand the rational onslaught from a new school, now generally known as the Ash'arite. This school tried to provide a logical and rational defense of Islamic beliefs and practices. Its leaders were Abu al-Hasan al-Ash'ari (d. 332/943) in Iraq and Abu Mansur al-Maturidi (d. 333/945) in Central Asia, followed by a number of other stalwarts like al-Baqillani (d. 
403/1012), al-Juwayni (d. 478/1085), and al-Qushayri (d. 465/1072). They were all extremely well-versed in religious sciences as well as 'ilm al-kalam and philosophy. However, they were generally conservative, although in different degrees, al-Maturidi being significantly less conservative than alAsh'ari. $^{21}$

It was, however, al-Ghazali (d. 505/1111) who inflicted the most stunning and fatal blow to the extreme rationalists. In his book, Tahafut alfalasifa (Incoherence of the Philosophers), completed in $488 / 1095,{ }^{22}$ he logically exposed the "inconsistency of their metaphysical beliefs and selfcontradiction of their theories. ${ }^{.23} \mathrm{He}$ succeeded because he attacked philosophy "with full knowledge of its contents and all the force and clarity of his vigorous mind." ${ }^{24}$ However, he did not believe in rejecting everything that the rationalists stood for. He clearly stated that "If what they [the philosophers] say is sensible in itself, supported by evidence, and not in conflict with the Qur'an and the Sunnah, then it is not becoming of us to reject it. If we open the door of rejecting every truth that a heretic has arrived at, we will be constrained to reject a great deal of truth." ${ }^{25} \mathrm{He}$ took from them whatever appeared to him to be useful and tried to create a synthesis of philosophy, 'ilm al-kalam, and the Islamic sciences and was thereby able to resolve rationally a number of the existential disputes prevailing in his time. He was thus able to create, in the words of Arnaldez, "the richest, widest and most open system."26

Of the twenty theories of the rationalists that he found objectionable, he considered only three to be heretical and totally unacceptable. These were eternity of the world, impossibility of bodily resurrection, and divine ignorance of particulars. ${ }^{27} \mathrm{He}$ argued that these theories for which the philosophers claim the same degree of certainty and incontestability as mathematics and logic, were based essentially on unproved assumptions and conjectures that could not be established by reason. ${ }^{28} \mathrm{He}$ had no qualms about accepting the other theories which he did not find to be in conflict with the Shari'ah and which had a scientific basis. He particularly supported their explanations for a number of natural phenomena, like the lunar and solar eclipses, because rejection of such explanations would do harm to religion. ${ }^{29}$ Physics, chemistry, astronomy, mathematics, and other such physical sciences were upheld without any grudge. He stated boldly that "he who considers that Islam will be helped by the rejection of these sciences, has committed a grave crime against religion (din). ${ }^{130} \mathrm{He}$ did not question the role of reason in human affairs. In fact, he emphasized that "intellect is the 
fountainhead, starting point, and foundation of knowledge. Knowledge proceeds from it just like fruit from the tree, light from the sun, and vision from the eye." ${ }^{31} \mathrm{He}$, however, questioned the reliance on reason alone to establish metaphysical truths and to distinguish right from wrong. Reason and revelation must both play a complementary role in human life.

What provided further strength to al-Ghazali's rational defense of Islamic beliefs and practices was his vast knowledge of philosophy as well as the Shari'ah and his high moral caliber. These earned for him great respect and admiration. He came to wield considerable influence in the then Muslim world and continues to be widely read and quoted to this day. It is because of him that 'ilm al-kalam, which was introduced by the Mu'tazilites and incorporates extensively the vocabulary and arguments of the falasifa, became one of the officially recognized religious sciences and an essential part of the religious syllabi.

However, while al-Ghazali rendered a great service to Islam by rationally defending its beliefs and practices against the attacks from heretics and extreme rationalists, he went off on a tangent by insisting that the cause of every phenomenon is God, thereby de-emphasizing the role of efficient (or immediate) causes. He said that "the relationship between what is normally considered to be the cause and what is considered to be the effect is not necessary." ${ }^{32}$ To prove this point, he argued that the relationship between quenching of thirst and drinking, satisfaction of hunger and eating, burning and contact with fire, and healing and use of medicine is as destined previously by God. ${ }^{33}$ It was a little odd for him to deny the role of efficient causes and yet recognize the importance of physical sciences, one of the central pillars of which is the establishment of cause and effect relationships. Even though he does not seem to have laid much stress on this point, he ended up strengthening the extreme conservatives who have been responsible for weakening rationalism and scientific inquiry in the Muslim world. One therefore wonders why a scholar of his caliber decided to toe the Ash'ari line of denying the obvious relationship between cause and effect. It may probably have been an unconscious outcome of the prevailing climate of confrontation and suspicion created by the denial of fundamental epistemological realities by the extreme rationalists. He may have been afraid that acceptance of the crucial role of efficient causes in various phenomena in human life might indirectly imply the irrelevance of God in human affairs and thereby His relegation to the role of a clock-maker deity. Even 
though such a fear seems now to have been unfounded, it could have been real in the intellectual climate confronting al-Ghazali.

Ibn Rushd (d. 595/1198) made a last gigantic effort to save the rationalist movement from collapse nearly eighty-five years after al-Ghazali's fatal blow. He prepared a rejoinder, which was completed in 576/1180 and published under the title, Tahafut al-tahafut (Incoherence of the Incoherence) ${ }^{34}$ The two Tahafuts, of al-Ghazali and Ibn Rushd, clearly reflect the essence of the conflict of ideas about reason and revelation that prevailed in the Muslim world from the second/eighth to the seventh/thirteenth centuries and that arose in the West five centuries later.

A number of the charges that al-Ghazali leveled against philosophers did not apply to moderate philosophers like Ibn Rushd, whose thinking on Islamic beliefs and practices largely conformed with orthodoxy. Ibn Rushd had realized the weak position of the extreme rationalists on a number of points and had, therefore, adopted a conciliatory attitude, stressing the role of both revelation and reason in religion. He stated that "Every religion is based on revelation (wahi), but reason ('aql) gets blended with it. He who holds that there can be a religion based only on reason concedes that this religion will necessarily be less perfect than those based on both reason and revelation." ${ }^{35} \mathrm{He}$ also stressed that "to walk on the path of religious virtues is indispensable" 36 and that "it is the duty of every person to select the best religion of his time." ${ }^{37}$ Having admitted the need for religion, he goes on to defend the moderate philosophers by clarifying that "the wise among the philosophers do not permit discussion or disputation of the principles of religion." ${ }^{38} \mathrm{He}$ even went to the extent of asserting that "those who have doubts about these matters [religious truths] and are eloquent in disputing them are the ones who wish to destroy the religions and to undo the virtues. They are undoubtedly the heretics who believe that the end of man is nothing but sensual enjoyment ... What al-Ghazali says against them is right." 39 In his Fasl al-maqal, he makes a strong case for the mutual compatibility of both reason and the Shari'ah.

However, Ibn Rushd tried to rectify the error of al-Ghazali with respect to efficient causes. He argued forcefully that even though the ultimate cause of every phenomenon is God, He has established a secondary cause for every phenomenon. While $\mathrm{He}$ is capable of bringing about satiety without eating, quenching of thirst without drinking, and burning without contact with fire, $\mathrm{He}$ does not normally do so. When $\mathrm{He}$ does do so, it becomes a miracle, which is among "divine acts and beyond the reach of human intel- 
lect." ${ }^{40}$ It is because of this that "none of the previous philosophers discussed miracles in spite of their existence in the world." 41 Therefore, "to deny the existence of efficient causes observed in phenomena perceptible through the senses is sophistry." 42 Knowledge, according to Ibn Rushd, progresses through the establishment of cause and effect relationships. "Denial of causes implies the denial of knowledge, and denial of knowledge implies that nothing in this world can be truly known and that there can be only unlimited assumptions without evidence." 43

In spite of his brilliance and profound scholarship, Ibn Rushd could not swing the prevailing opinion in favor of the philosophers. Hence, even though he played an important role in the history of the Latin Middle Ages, ${ }^{44}$ he had little influence on Muslim thought and has the distinction of being perhaps the last of the great philosophers in the Muslim world. ${ }^{45}$ " $\mathrm{He}$ had no disciples or followers." ${ }^{46}$ This was undoubtedly a great misfortune for the Muslim world, not only in the realm of rationalism but also in the field of fiqh, where his treatise, Bidayat al-mujtahid, continues to be a respectable source of reference for scholars even today. ${ }^{47} \mathrm{He}$ believed in creating a balanced fusion of reason and revelation (al-jam' bayn al-ma'qul wa al-manqul) by giving reason and experiment (al-qiyas wa al-tajribah) a rightful place in the Shari'ah, and he was critical of those who rigidly and uncritically followed the opinions of their predecessors. ${ }^{48}$ His scientific approach to problems, his depth of vision, and his liberal and tolerant attitude could have been a great asset in molding the course of intellectual activity in the future.

Even the government patronage that the rationalists enjoyed could not continue when the caliphs became weaker and needed public support. They could not, therefore, afford to persist in alienating the masses by ignoring the Islamic basis of society. They were left with no other option but to return to the consensus view. ${ }^{49}$ Hence, scholars like Ibn Rushd fell into disgrace. The rationalist movement lost its momentum and became considerably weakened. With hardly anyone left to challenge it, the Ash'ariyyah movement had a field day. It became the dominant school in the Muslim world and has continued to be so until today, thanks to prominent defenders like al-Shahrastani (d. 548/1153), Fakhr al-Din al-Razi (d. 606/1209), al-Iji (d. 756/1355), and al-Jurjani (d. 816/1413).

By the time Ibn Taymiyyah (d. 728/1328) wrote his Kitab al-Mantiq (The Book on Logic), the philosophical movement had become totally discredited. He went so far as to say that "there is no philosophy in Islam" and that 
"the philosophers are not Muslims." ${ }^{50}$ The reason for this was not their cause and effect analysis but rather their berserk speculative philosophy. $\mathrm{He}$, however, upheld the quest for establishing cause and effect relationships and attacked the Ash'ariyyah for their denial of efficient causes, saying that "people know through their sense perceptions and intellect that some things are the causes of others." ${ }^{" 1}$ According to him those who deny efficient causes are violating the Qur'an and the Sunnah and the ijma' (consensus) of the pious predecessors (salaf).$^{52}$

Ibn Khaldun (d. 808/1406), who was himself a great rationalist and supporter of reason and of cause and effect analysis, was more careful in his characterization of the philosophers, but even he places speculative philosophy among the discredited sciences like magic, astrology, and alchemy, in the chapter "Refutation of Philosophy." ${ }^{3}$ The rationale he gives for this is that the philosophers did not acknowledge their limitations and did not realize that the universe was too vast and complex to be comprehended in its entirety by human reason and sense perceptions. It was a vain pretension on their part to assume that they could reach the ultimate truth by merely applying the rules of logic..$^{54}$

Al-Maqrizi (d. 845/1442) was not as careful as Ibn Khaldun in his characterization of philosophers and went even farther than Ibn Taymiyyah in classifying the philosophers among those who were opposed to Islam (mukhalifun) ${ }^{55}$ Such a charge may not be true except for a few heretics among them like Ibn al-Rawandi. Most of them remained true Muslims and were generally considered to be within the pale of Islam. However, as indicated earlier, their extremism, intolerance, and use of force set the image and drew the response. Al-Maqrizi's characterization reflects the negative image that this behavior had aroused for the rationalist movement.

This negative image proved to be tragic for the Muslim world. It not only weakened the rationalist movement but gradually drove the Muslim world more and more toward greater conservatism through the operation of path dependence and self-reinforcing mechanisms. The vigor and dynamism that characterized Muslim scholarship during the late Umayyad and early Abbasid periods, when no discussion was considered to be a taboo, became substantially diluted. Not just philosophy but also the associated physical sciences got totally excluded from the syllabi of religious schools. Since the governments also did not pay as much attention to science education and research as they did in the earlier centuries, the stage was set for the neg- 
lect of science education, without which it was difficult to strengthen the roots of rationalism in society.

If the Muslim scholars of that period were to be classified according to their commitment to rationalism or conservatism, they would fall into the following four groups: extreme rationalists like Ibn al-Rawandi (d. 250/864) and Abu Bakr al-Razi (d. 313/925), who aspired to attain all metaphysical truths by means of reason alone without the help of revelation; moderate rationalists like Ibn Rushd (d. 595/1198), who accepted the need for both revelation and reason; moderate conservatives like al- Ash'ari (d. 332/943), al-Maturidi (d. 333/945) and al-Ghazali (d. 505/1111), who recognized the role of reason but less than what would be acceptable to the moderate rationalists; and extreme conservatives like the Hashwiyyahs, who insisted on blind faith in the acceptance of religious beliefs and denied any role for reason in even the elucidation and defense of faith. Out of these four groups, the extreme rationalists lost ground just like the extreme conservatives. The moderate conservatives, however, carried the day.

The tragedy, however, is that self-reinforcing mechanisms moved the moderate conservatives gradually over the next few centuries toward greater conservatism and rigidity, making it more and more difficult for even the moderate rationalists to breathe freely. While it was possible in the earlier centuries for scholars like al-Ash'ari, al-Ghazali, Ibn Rushd, and innumerable others to get a solid grounding in both religious and mundane sciences if they so desired, it became more and more difficult for them to do so with the passage of time. Science education did not return to the Muslim world in a significant way until after the colonization of a major part of it by the West. However, a combination of the two which was relatively easy in the earlier centuries is still difficult.

\section{Contrast with the Western Enlightment Movement}

In short, what hurt the rationalist movement, which had a great initial appeal and general acceptance, was its failure to appreciate the limits of reason, intolerance of opponents, and use of state coercive power to impose its views on the population. This led to the politicization of an otherwise intellectual debate, raised tempers, and hardened attitudes. What was particularly offensive in the whole affair was that the views being imposed were in conflict with some of the fundamental, well-accepted, and rationally defensible Islamic beliefs. ${ }^{56}$ The greatest damage was caused by the doctrine of the "created Qur'an." The confrontation that had been artificially provoked kept some of the best minds of the Muslim world occupied for 
centuries with unproductive hair-splitting debates. If force had not been used, the fear may perhaps not have been accentuated to such an extent, confrontation may not have been created, attitudes may not have hardened, and an unbridgeable rift between the government and the "ulama and between philosophy and religion may perhaps not have developed. This rift proved to be tragic for the development of both fiqh and physical sciences in the Muslim world.

The reasons for the downfall of the "Enlightenment" movement in the Muslim world were thus the reverse of what led to its success in the West. First, in the West it was the corruption and despotism of the Church which led to the success of Voltaire's call "crush the infamous thing" and shook confidence in the metaphysical beliefs that the Church stood for. ${ }^{57}$ Voltaire wrote in his Treatise on Toleration that he would have borne with the absurdities of dogma, had the clergy lived up to their sermons and tolerated differences, but "subtleties of which not a trace can be found in the gospels are the source of the bloody quarrels of Christian history." ${ }^{58}$ Durant in fact asserts that "the Church might have sustained the supernatural sanctions provided by the Hebraic Scriptures and the Christian tradition if her personnel had led lives of decency and devotion." 59 In contrast with this, most, if not all, of the great religious scholars in the Muslim world like Abu Hanifah (d. 150/767), Malik (d. 179/795), Shafi'i (d. 204/820), and Ahmad ibn Hanbal (d. 241/855) were individuals of great piety and integrity who commanded the respect and confidence of the people. They were not men of great wealth and, in general, refused to accept political appointments, even though these were offered to them to silence their criticism of the corruption and un-Islamic practices of the rulers and their associates.

Second, as Hourani has rightly pointed out, "orthodoxy in Islam has never been defined by ecclesiastical councils, as in Christianity. No such councils have been held, due to the absence of an ordained priesthood in Islam." 60 Orthodoxy has rather been defined by the Qur'an and the Sunnah and the ijma' or consensus of the Muslim ummah, reached through the free discussion of the "ulama (religious scholars) who, according to a widely quoted and authentic hadith, are warathat al-anbiya' (the legatees of the prophets). The effort of the state to define the contents of the Shari'ah came to end with the end of the mihnah. ${ }^{61}$ While Western scholars have successfully challenged the authenticity of the Bible, Muslims have, as Ansari has rightly put it, "recognized the paramount authority of the Qur'an and the Sunnah of the Prophet" 62 from an early period. All beliefs and religious and 
legal doctrines have been derived from these. The "ulama, around whose opinions the consensus developed, did not impose their views on the people. The people, in fact, accepted their views because of their harmony with the Qur'an and the Sunnah as well as the force of their logic and the confidence in their piety, integrity, and scholarship.

Third, while it was the Church that resorted to inquisition in the West, it was the rationalists who resorted to it in the Muslim world, though never as harshly as the Church. Burning of live human beings resorted to by the Church never took place in Islam. Nevertheless, it left an unhealthy mark. This is because repression generally tends to create a severe reaction and leads the repressed to extremism. Its use by the Church hurt religion in the West, and its use by the Mu'tazilites hurt rationalism in the Muslim world. If the debate between the Mu'tazilites, many of whom were respected religious scholars, and the conservatives had been allowed to progress freely without the use of force, rationalism and orthodoxy may both have been enriched and more balanced views may perhaps have gotten established.

Fourth, while the church stood for a number of beliefs, which could not be defended rationally and for which there was no basis in the gospels, some of the extreme views of the philosophers and the Mu'tazilites had no basis in the Qur'an or the Sunnah and could not even be defended rationally. As compared with this, the beliefs held by the "ulama as well as the people had their footing in the Qur'an and the Sunnah and were relatively simple and easy to understand.

\section{The Future of Rationalism in the Muslim World}

We now come back to the question raised earlier about whether the reemergence of scientific inquiry in the Muslim world may give rise to a conflict between reason and revelation and necessitate a change in the paradigm in the same way as it did in the West. The Islamic paradigm does not itself necessitate a conflict between reason and revelation.

During the first two centuries of Islam there was a free debate on all issues on which there was difference of opinion. According to Ibn Taymiyyah (d. 728/1328), no jurist, irrespective of who he may have been, was considered at that time to have the right to impose his opinion on others and to force them to adopt his madhhab or juristic school. ${ }^{63}$ Even a ruler did not enjoy this privilege. He was like one of the Muslims. All he could do was to argue logically and intellectually in favor of his opinion. ${ }^{64}$ That was perhaps the reason why, when Caliph Harun al-Rashid (d. 193/809) 
thought of making all his subjects follow Malik's al-Muwatta', Malik (d. 179/795) himself advised him against doing so. ${ }^{65}$ This would have been against the spirit of freedom of opinion in Islam. It was during this period that Islamic jurisprudence witnessed maximum development. ${ }^{66}$ If the Mu'tazilites had abided by this precedent of Muslim society, they may not have aroused the tempers and the heat that they did. The conflict between the rationalists and the conservatives may not then have taken the hostile and belligerent turn it took. There would be no justification for this because of the following two important reasons.

First, the Qur'an itself strongly emphasizes the use of reason and observation. This emphasis has generally become reflected in the writings of Muslims throughout history. For example, Ibn Taymiyyah clearly stresses that the derivation by Muslims of their beliefs, prayers, and values from the Qur'an, the Sunnah, and the consensus of the ummah "is not in conflict with reason, because whatever clearly contradicts reason stands rejected (batil)." ${ }^{\prime 67} \mathrm{He}$ further argues that people often do not appreciate that the texts of the Qur'an and the Sunnah consist of words and that it is possible for them to understand these words incorrectly or to interpret them wrongly. So the problem lies with the interpreters and not the Qur'an and the Sunnah. ${ }^{68}$ Mustafa al-Zarqa, a prominent and highly respected contemporary religious scholar, also clearly declares that "whatever is against reason has no place in Islam." 69 Moreover, there is nothing in the Qur'an or the Sunnah that has so far been found to be in conflict with an established fact or scientific theory.

Second, as stated earlier, the Mu'tazilites did a great deal to defend Islam against the heretics, and many of their views were rational and in harmony with the Qur'an and the Sunnah. ${ }^{70}$ If the heat had not been created by excesses and inquisition, all issues might perhaps have been discussed relatively freely, and it is most likely that even the relatively moderate rationalists like Ibn Rushd may also have survived along with the moderate conservatives or Ash'arites like al-Ghazali. Over time, the presence of a lively discussion between them may have helped resolve the prevailing controversies in a rational manner. This would have made it difficult for the Ash'arites to tilt later on toward increasing conservatism and rigidity and to use force in the same way as the Mu'tazilites did to uphold and spread their views. ${ }^{71}$ The dual survival of both moderate rationalists and moderate conservatives might have served as a balancing force that would have exerted a healthier influence on the Muslim society. It may also have led to the inte- 
gration of science and religious education and perhaps also to the promotion of a relatively more liberal development of fiqh in the Muslim world.

What the Mu'tazilite excesses did, therefore, was to bedevil the atmosphere of intellectual freedom that prevailed in the earlier centuries. This tended to push the pendulum in the opposite direction. All free thinking became suspect and set up an attitude of extreme caution and conservatism in the expression of opinions on religious issues. Consequently ijtihad suffered. It did not, fortunately, stop completely. ${ }^{72}$ Voices were always raised in its favor and it continued to be exercised by some highly competent, respected, and creative scholars, though not as frequently as in the early centuries. $^{73}$

In addition to the Mu'tazilite excesses, there were some other factors which seem to have strengthened this tendency toward rigidity and conservatism. One of these was the desire of the illegitimate and corrupt political elite to extract juristic verdicts to help them justify their illegitimacy and oppressive taxes. Therefore, as Muhammad Iqbal (d. 1357/1938), the highly respected and renowned philosopher/poet of the Indo-Pakistan subcontinent, has rightly indicated:

For fear of further disintegration, which is only natural in such a period of political decay, the conservative thinkers of Islam focused all their efforts on the one point of preserving a uniform social life for the people by a jealous exclusion of all innovations in the law of the Shari'ah as expounded by the early doctors of Islam. Their leading idea was social order and there is no doubt that they were partly right, because organization does to a certain extent counteract the forces of decay. ${ }^{74}$

A second factor which reinforced conservatism was foreign domination, starting with the Mongols. This raised the fear that the foreign occupiers may try to use some of the jurists to get verdicts that may serve their vested interest and change the texture of the Shari'ah.

A third factor was the overall decline in the Muslim world. Intellectual development, as Ibn Khaldun rightly observed, takes place in a society only if the society itself is developing. ${ }^{75}$ Jurisprudence could not be an exception. It also tended to be influenced by the prevailing stagnant socioeconomic and political environment. It was bound to be in a state of limbo when the Muslim society had become generally fossilized and was in the process of decline. Not only did an enabling environment for intellectual creativity not exist, but there was hostility toward any change, irrespective 
of whether it was or was not in harmony with the Shari'ah. Ibn Taymiyyah (d. 728/1328) and Shah Waliyullah (d. 1176/1762), who were both creative and relatively liberal scholars, as compared with the rigid and fossilized schools of fiqh prevailing in their times, encountered considerable opposition for their independent, non-conformist views. Shah Waliyullah experienced serious opposition even for his translation of the Qur'an into Persian as did his sons when they translated it into Urdu. ${ }^{76}$ However, since the government did not intervene in favor or against, the more rational view prevailed ultimately and has become generally accepted to the point that no one now considers anything wrong in principle in the translation of the Qur'an in any language.

Reason can thus play a considerable role in the restructuring of Muslim society without coming into conflict with revelation, provided that the state, the rationalists, and the conservatives do not try to step on each other's toes and avoid confrontation and use of force. In spite of a substantial decline in the position of the 'ulama as a result of their low socio-economic status and lack of modern education, their upper hand in defining Islam, nevertheless, continues in the Muslim world, as Gibb rightly recognized in 1947: "The future of Islam rests where it rested in the past - on the insight of the orthodox leaders and their capacity to resolve the new tensions as they arise by a positive doctrine which will face and master the forces making for disintegration." 77 The historical experience suggests that if the political leadership tries to impose, in the same way as the Abbasid caliphs did, ${ }^{78}$ views which the "ulama consider to be in clear conflict with the ethos of Islam, they may end up raising tempers, hardening attitudes, and creating a conflict and polarization in the same way as happened in the past. ${ }^{79}$ Such a conflict would almost certainly slow down the process of change and liberalization in the Muslim world.

Seventy years of forced secularism in Turkey has not succeeded in shaking people's faith in Islam, and there is now a revival. Some other dictatorial regimes in Muslim countries are also trying to impose their own version of Islam on the people, and this may also not work. Free and amicable discussion, without attacking the Islamic basis of society, is necessary for resolving various issues. The Qur'an and the Sunnah are both an integral part of the Islamic paradigm, and anyone who suggests the setting aside of both, or even the Sunnah, in the reconstruction of Muslim societies is bound to generate an extreme reaction. So much flexibility of interpretation seems to be possible within the Shari'ah itself that an extreme attitude of 
this kind may be unrealistic and uncalled for. What the state may do is to facilitate a free and open discussion between the various shades of rationalists and conservatives. Those whose views are more convincing may ultimately prevail.

The caveat, however, is that if the 'ulama become intolerant and, instead of being prepared to end their stagnation and inflexibility, react aggressively and harshly to even moderate forms of rationalist thinking, which are necessary for enabling the fiqh to meet the challenges faced by the Muslim ummah, then there might arise an adverse reaction. This might swing the pendulum in the direction of extreme rationalism, as it did in the West, and thus damage not only Islam but also the position of the "ulama themselves. To prevent this from happening, it may be helpful if modern sciences and at least one Western language, particularly English, is introduced as a compulsory subject in the syllabi of all institutions of Islamic learning, and if religious education is made an integral part of modern education. This may help create a better and more congenial atmosphere for a dialogue between the graduates of Western and religious institutions and thereby lead to greater mutual understanding and meaningful discussion of various issues.

Fortunately, however, the rigidity of the 'ulama seems to have steadily declined over the years as a result of the efforts initiated by people like Jamaluddin Afghani (d. 1315/1897), Muhammad 'Abduh (d. 1323/1905), Muhammad Iqbal (d. 1357/1938), and a number of other learned and wellrespected scholars and reformers. The 'ulama are no longer involved in the same hair-splitting debates they were in the past. The institution of ijtihad has also become gradually revived, and liberal thinking within the limits of the Shari'ah does not raise the eyebrows or create the same kind of adverse reaction as it did, say, in the eighteenth century during the lifetime of Shah Waliyullah. The 'ulama seem to have realized, though not adequately, that the world has moved forward substantially since the days of classical fiqh compendiums. Accordingly, the rigid juristic positions adopted on a number of issues seem to be losing ground in favor of relatively more liberal views, which are not only possible without coming into conflict with the Qur'an and the Sunnah, but also are necessary in view of changing circumstances. The absence of a monolithic Church or an ecclesiastical council has also proved to be a great advantage. It has enabled liberal as well as conservative shades of opinion on various juristic issues to interact with each other. The independence of almost all Muslim countries from foreign domination, and the pressing need that this has created for finding solutions 
to the various problems encountered in the political, social, economic, and educational fields, seems to be giving an edge to the relatively more liberal jurists. The fiqh committees of the Organization of Islamic Conference, the Rabita, and the individual member countries, are doing valuable work at the international and national levels. The revival of the institution of shura in a number of important Muslim countries may add further strength to the liberalization process.

It seems that the thrust of the Qur'an and the Sunnah in favor of creating greater flexibility and ease is being increasingly realized. The Qur'an states that "God intends ease for you and not hardship" (al-Qur'an, 2: 185; see also 5:6). The Prophet, peace and blessings of God be on him, said: "The Islamic way of life (al-din) is easy; whoever tries to make it hard gets himself overpowered by it [he is unable to practice it]." ${ }^{\text {" Th }}$ The increasing volume of literature on the maqasid (goals) is also a reflection of the realization that the taking of these into account in the interpretation of texts is at least as important as the letter of the text. It may be hoped that this development may continue steadily until it has led to the consolidation of all the schools of jurisprudence in such a way that their different verdicts on various issues acquire the nature of different possible alternatives from which an individual, group, or nation may select the one that is most suitable for its specific circumstances.

The problem, however, is that modern rationalists are, like their counterparts in the past, a heterogeneous group. There are those who are moderate. They are positive with respect to Islam and its values and are doing what they can to present a convincing case for breaking the thick crust of rigidity, which is necessary for enabling Islam to meet the challenges it faces in a world where secularism is still the dominant paradigm. They are not only not creating any problems but seem to be gradually making a headway. There is, however, another group, consisting of extreme secularists who would like to push aside the Qur'an and the Sunnah and reconstruct Muslim societies in the image of the West. However, even the West is not a homogenous whole. It has religious as well as anti-religious and hedonistic elements. The extreme secularists wish the Muslim world to follow the path of the latter. They are generating conflict and tension and using force to impose their views, just like the Mu'tazalites, by virtue of the political power that some of them now have at their command. Force did not succeed in the past, and is not likely to do so now. In fact, it may only serve to create a more aggressive and extremist response from the conservative 
forces. This may prove to be a hurdle for even the moderate rationalists in moving their societies toward a healthier balance as it did in the past.

The spread of democracy has fortunately changed the scenario in favor of moderation. If the political parties do not wish to be disappointed at the polls, they have to appeal to all sectors of the population. Since the masses have a strong attachment to Islam, the effort to create a dichotomy between the sacred and the secular of the kind that took place in the West and that the secularists wish to bring about may be frustrated. Extreme orthodoxy may likewise fail because it does not fit into the pluralist framework of modern democratic societies. The demand for socio-economic and political reforms, to redress the condition of the masses and to realize the Islamic imperative of socioeconomic justice, will necessitate not only greater integrity in the use of government resources, but also the establishment of priorities and the employment of more realistic strategies. The corrupt secularist bureaucracies as well as the extreme orthodoxies may be unable to realize these, the former, because of their corruption, inertia, and loyalty to internal or external vested interests, and the latter because of their lack of a proper understanding of the complexities of modern economies, suspicion of everything foreign, and refusal to borrow from successful strategies employed elsewhere. The result may be a move toward realism and the adoption of a strategy tailored to the promotion of development with justice and stability in the light of the experience of other countries, but without coming into conflict with the Shari'ah.

\section{Notes}

1. See George Sarton, Introduction to the History of Science (Washington: Carnegie Institute, 3 volumes published between 1927-1948; the 2nd and the 3rd in two parts each); and Fu'ad Sezgin, Tarikh al-Turath al-Arabi (History of Arab Legacy); tr. Mahmud Fahmi Hijazi (Riyadh: Imam Muhammad ibn Saud Islamic University, first volume 1983, followed by other volumes in later years).

2. The word itazala means to withdraw, detach, or isolate, and the term Mutazila is used to signify the movement whose followers had "withdrawn" themselves from the extremist views of the Kharijites and the Murji'ites and chose to follow the middle path (manzilah bayn al-manzilatayn). See Abu Zahrah, Tarikh al-Madhahib al-Islamiyyah (Damascus: Dar al-Fikr al-Arabi, n.d.), vol. 1, pp. 156-157; and Mir Valiuddin, "Mu'tazilism," in M.M. Sharif, ed., A History of Muslim Philosophy (Wiesbaden: Otto Harrasowitz, 1963), vol. 1, 199-200. The movement started under the leadership of Wasil ibn 'Ata' (d. $131 / 748)$ and lated included in its fold a number of other stalwarts like Abu al-Hudhayl (d. 226/841), Ja'far ibn al-Bishr (d. 226/841), al-Nazzam (d. 231/845), al-Jahiz (d. 255/869), alJubba'i (d. 295/908), and 'Abd al-Jabbar (d. 415/1024). Although the movement stretched over a period of almost five centuries, its classical period lasted for nearly two centuries from approximately the last quarter of the third/ninth century to the middle of the fifth/eleventh century. For some details on their views, see Abi al-Fath Muhammad ibn 'Abd al-Karim al-Shahrastani (d. 548/1153), Al-Milal wa al-Nihal, ed., Muhammad Sayyid Kaylani (Cairo: Mustafa al-Babi al-Halabi, 1961), vol. 1, 43-91; and 'Abd al-Qahir ibn 
Tahir al-Baghdadi (d. 429/1037), Al-Farq Bayn al-Firaq (Beirut: Dar al-Kutub al-'Ilmiyyah, n.d.), 78-150. See also Valiuddin, "Mu'tazilism," 1963, 204-218; D. Gimaret, "Mu'tazila," in The Encyclopaedia of Islam, vol. 7, 1993, 783-793; and L. Gardet, "'Ilm al-Kalam," in The Encyclopaedia of Islam, vol. 3, 1971, 1141-1150.

3. Al-Farabi (d. 339/350) defined 'ilm al-kalam in his Ihsa' al-'ulum as "a science which enables a person to ensure the victory of beliefs and practices laid down by the Shari'ah or God, the Provider of the Sharitah, and to logically refute all opinions contradicting them." $\mathrm{Al}$-Iji (d. 756/1355) defined it in his Kitab al-mawaqif fi ' ilm al-kalam as "the science which is concerned with firmly establishing beliefs by supplying proofs and removing doubts." (Both definitions adapted with minor modifications in the translation from Gardet, " $\mathrm{Ilm}$ alkalam," 1971, 1141). In between the two, al-Ghazali (d. 505/1111) specified the purpose of 'ilm al-kalam to be "to protect the Islamic faith and to defend it against the skepticism of heretics" (Abu Hamid al-Ghazali, al-Munqidh min al-dalal, along with three other books of al-Ghazali, Kimya' al-sa'adah, al-Qawa'id al-'asharah, and al-Adab fi al-din, ed., Muhammad Muhammad Jabir (Beirut: Al-Maktabah al-Thaqafah, n.d.), 14. Al-Munqidh has been translated into English by W. Montgomery Watt under the title The Faith and Practice of al-Ghazali (London: George Allen and Unwin, 1953).

4. Gardet, "Ilm al-kalam," 1971, 1142.

5. Abu Zahrah, Tarikh al-madhahib, vol. 1, 162-163; Abu Hamid al-Ghazali, Tahafut al-falasifah, ed., Jirar Jihami (Beirut: Dar al-Fikr al-Lubnani, 1993). An English translation by Sabih Ahmad Kamali was published in 1963 by the Pakistan Philosophical Conference, Lahore, 26 (see p. 26).

6. The first Muslim philosopher is generally acknowledged to have been al-Kindi (d. 252/866), followed by a number of other illustrious names like Abu Bakr al-Razi (d. 313/925), al-Farabi (d. 339/950), Ibn Sina (d. 428/1037), Ibn Bajjah (d. 533/1139), Ibn Tufayl (d. 581/1185), and Ibn Rushd (d. 595/1198).

7. For the difference of opinion among the rationalists, see al-Shahrastani (d. 548/1153), Al-Milal, 1961, vol. 1, 40-113 and 198-207.

8. The other three axioms were as follows:

- Reward and punishment (al-watd wa al-watid) are both necessary.

- A sinner is neither a believer ( $m u^{\prime}$ min $)$ nor an unbeliever (kafir). Rather he occupies an intermediate rank between the two (al-manzilah bayna al-manzilatayn). $\mathrm{He}$ is a malefactor (fasiq).

- It is the obligation of a Muslim to command the good and to forbid the evil (alamr bi al-mairuf wa al-nahi 'an al-munkar). See al-Sharastani (d. 548/1133), AlMilal, 1961, vol. 1, 43-46.

9. Even the Prophet, may the peace and blessings of God be on him, acknowledged this in a well-known and oft-repeated prayer, saying: "I cannot praise You fully; You are as You have described Yourself."

10. For some details about the extreme rationalists and their views, see Abdurrahman Badawi, Min tarikh al-ilhad fi al-Islam (Beirut: Al-Mu'assasah al-'Arabiyyah li al-Dirasat wa al-Nashr, 2nd ed., 1980); and also Badawi, "Muhammad ibn Zakariyyah al-Razi," in Sharif, A History of Muslim Philosophy, vol. 1 (1963), 439-440.

11. See John Hicks, "Revelation," in The Encyclopaedia of Philosophy, vol. 7 (1967), 189-191. See also Julian Huxley, Religion Without Revelation (London: 1947, 2nd ed., 1957); and Ronald Hepburn, Christianity and Paradox (London, 1958).

12. P. Kraus, "Ibn al-Rawandi," in The Encyclopaedia of Islam, vol. 3 (1971), 905-906.

13. Cited from al-Kindi's book, The Governors and Judges of Egypt, ed. R. Guest (London-Leiden, 1912) by Hinds, "Mihna," in The Encyclopaedia of Islam, vol. 7, (1993), 2-6.

14. Abu Zahrah, Tarikh, vol. 1, 178.

15. Cited from al-Kindi by Hinds, "Mihna," 4.

16. Abu Zahra, Tarikh, vol. 1, 183 .

17. Hinds, "Mihna," 4, cited on the authority of al-Tabari and al-Ya'qubi. 
18. See Abu al-Hasan Ali al-Mas'udi (d. 346/957), ed. M. Muhay al-Din 'Abd al-Hamid, Muruj al-dhahab wa ma'adin al-jawhar, vol. 4 (Beirut: Al-Maktabah al 'Asriyyah, 1988), 52; Abu Zahrah, Tarikh, vol. 2, 297-302. See also W.M. Patton, Ahmad ibn Hanbal and the Mihnah (Leiden, 1897), cited by A.J. Arberry, Revelation and Reason in Islam (London: George Allen and Unwin, 1957), 19; and Hinds, "Mihna," 3.

19. Cited from al-Kindi, by Hinds, "Mihna," 4.

20. See Hinds, "Mihna," 6.

21. Abu Zahrah, Tarikh, vol. 1, 212.

22. Abu Hamid al-Ghazali (d. 505/1111), Tahafut (1993). The word tahafut has been translated into English in different ways, including "breakdown," "disintegration," "absurdity," "bankruptcy," "inconsistency" and "incoherence." "Incoherence" may perhaps reflect the meaning more closely. Van Den Bergh, tr., Averroe's Tahafut al-tahafut (The Incoherence of the Incoherence) (Cambridge, U.K.: The Gibb Memorial Trust, 1969), 2 vols., xiii; also W. Montgomery Watt, Muslim Intellectual: A Study of al-Ghazali (Edinburgh: University Press, 1963), 59. Other books of al-Ghazali that are relevant to the subject under discussion are Al-Munqidh min al-dalal and Ihya' 'ulum al-din.

23. Al-Ghazali, Tahafut (1993), 28.

24. George F. Hourani, Averroes on the Harmony of Religion and Philosophy (A translation with introduction and notes of Ibn Rushd's Kitab Fasl al-maqal with its appendix [Damima] and an extract from Kitab al-kashf an manahij al-adillah) (London: Luzac, 1961), 5.

25. Al-Ghazali, Al-Munqidh min al-dalal, 31.

26. R. Arnaldez, "Falsafa," in The Encyclopedia of Islam, vol. 2 (1971), 774.

27. "Creation of the Qur'an" is not included among these twenty theories because this theory had been put to rest in 234/849 during the reign of Caliph al-Mutawakkil (232-247/847-861), long before al-Ghazali.

28. Al-Ghazali, Tahafut, 31 .

29. Ibid., 33.

30. Al-Ghazali, al-Munqidh, 25.

31. Al-Ghazali, Ihya' 'ulum al-din, vol. 1 (Cairo: Maktabah wa Matba'ah al-Mashhad alHusayni, n.d.), 83.

32. Al-Ghazali, Tahafut, 169.

33. Ibid., 169.

34. An English translation in 2 volumes by Simon Van Den Bergh was published in 1954 , reprinted in 1969, 1979, and 1987 by Luzac \& Co. (London). The second volume consists of only the translator's notes. See also Hourani, 1961, for a translation of selections from Ibn Rushd's Kitab fasl al-maqal and Kitab al-kashf'an manahij al-'adillah.

35. Ibn Rushd, Tahafut al-tahafut, ed., Maurice Bouyges (Beirut: Dar al-Mashriq, 3rd ed., 1992), 584.

36. Ibid., 527.

37. Ibid., 583.

38. Ibid., 527.

39. Ibid., 585-586. It may be useful for the reader to read the entire Fourth Discussion on pp. 580-586; it indicates that Ibn Rushd's views were perfectly in tune with orthodoxy and that his defense of philosophers (not heretics) was not unfounded.

40. Ibid., 527.

41. Ibid.

42. Ibid., 519.

43. Ibid., 522. It may be useful to read the whole section on efficient causes (pp. 519-527).

44. "Thomas Acquinas quotes Averroes no less than five hundred and three times." See Dominique Urvoy, tr., Olivia Stewart, Ibn Rushd (London: Routlege, 1991), 127.

45. Van Den Bergh, in the introduction to his translation of Ibn Rushd's Tahafut al-tahafut (1954), xii; and Gardet, "Ilm al-kalam," (1971), 1149. 
46. T.J. De Boer, The History of Philosophy in Islam, tr. Edward R. Jones (London: Luzac, 1970), 200.

47. This book has been translated into English in 2 volumes by A.K. Imran Nyazee, Theories of Islamic Law: The Methodology of Ijtihad (Islamabad: IIIT, 1994).

48. See Yasin Dutton, "The Introduction to Ibn Rushd's Bidayat al-Mujtahid," Islamic Law and Society (August 1994): 193.

49. See Watt, A study of al-Ghazali, 13

50. Ibn Taymiyyah, Majmu al-fatawa shaykh al-Islam Ahmad Ibn Taymiyyah, ed., Abd al-Rahman al-'Asimi, vol. 9 (Riyadh: Matabi' al-Riyadh, 1st ed., 1381-1383/1961-1963), 186.

51. Ibid., 288.

52. Ibid.

53. 'Abd al-Rahman ibn Khaldun, Muqaddimah (Cairo: Al-Maktabah al-Tijariyyah alKubra, n.d.). Ibn Khaldun includes metaphysics (ilahiyyat), magic and talisman, alchemy, philosophy, and astrology among the discredited sciences (495-531). However, Ibn Rushd had also criticized earlier in his Tahafut al-tahafut many of these sciences in a manner not significantly different from that of Ibn Khaldun. See Ibn Rushd, Tahafut al-tahafut (1992), 51. Ibn Khaldun's Muqaddimah has been translated into English in 3 volumes by Franz Rosenthal, Ibn Khaldun: The Muqaddimah, An Introduction to History (London: Routledge and Kegal Paul, 1st ed., 1958, 2nd ed., 1967).

54. Ibn Khaldun, Muqaddimah, 514-519; See also De Boer, The History of Philosophy in Islam (1970), 202.

55. Taqi al-Din Ahmad ibn 'Ali al-Maqrizi, Khitat al-Maqriziyyah, vol. 2 (Beirut: Dar Sadir, n.d.), 344.

56. Al-Ghazali, Tahafut (1993), 219-220; Abu Zahrah, Tarikh, vol. 1, 147-190.

57. See E.A. Burtt, The Metaphysical Foundations of Modern Science (Garden City, N.Y.: Doubleday, 1955), 237.

58. Voltaire, Selected Works, 62, cited by Will Durant, The Story of Philosophy (New

York: Washington Square Press, 1970), 237.

59. Durant, The History of Civilisation, vol. 5 (New York: Simon \& Schuster, 1954), 571.

60. Hourani, Averroes, 29.

61. Hinds, "Mihna," 6.

62. Zafar Ishaq Ansari, "The Contribution of the Qur'an and the Prophet to the Development of Islamic Fiqh," Journal of Islamic Studies (July 1992), 157.

63. Ibn Taymiyyah, Majmu al-fatawa, vol. 30, 80.

64. Ibid., vol. 35,360 .

65. Ibid., vol. 30, 79. Before Harun al-Rashid, Caliph Abu Ja'far al-Mansur (d. 158/775) had also thought of making all judges base their decisions on just one school of fiqh but was advised against doing so (see Mustafa al-Zarqa, Al-Fiqh al-Islami fi thawbihi al-jadid, vol. 1 (Damascus: Matabi' Alif Ba' al-Adib, 1967), 178.

66. See Mustafa al-Zarqa, Al-Fiqh, vol. 1 (1967), 147 and 171.

67. Ibn Taymiyyah, Majmu al-fatawa, vol. 11, 490.

68. Ibid.

69. See also Mustafa al-Zarqa, Al-'Aql wa al-figh fi fahm al-hadith (Damascus: Dar alQalam, 1996), 14.

70. See Abu Zahrah, Tarikh, vol. 1, 190.

71. For the use of force by the Ash'arites, see al-Maqrizi (d. 845/1442), al-Khitat, vol. 2, 358.

72. See Wael B. Hallaq, "Was the Gate of Ijtihad Closed?" Journal of Middle East Studies (March 1984): 3-41. See also Kate Zebiri, Mahmud Shaltut and Islamic Modernism (New York: Oxford University Press, 1993), 136.

73. Lewis acknowledges that "Muslim law has not been static, it has undergone a long, complex development. A careful scrutiny of juristic texts can produce valuable information on the changing conditions, pressures and influences to which the jurists were subject." See 
Bernard Lewis, "Sources for the Economic History of the Middle East," in M.A. Cook, ed., Studies in the Economic History of the Middle East from the Rise of Islam to the Present Day (London: Oxford University Press, 1970), 91.

74. Muhammad Iqbal, Reconstruction of Religious Thought in Islam (Lahore: Shaikh Muhammad Ashraf, 1954), 151.

75. Ibn Khaldun, Muqaddimah, 434.

76. Although this opposition to the translation of the Qur'an may appear to be irrational now, it may not have appeared to be so at that time. As A.J. Arberry has rightly put in the Introduction to his translation, The Koran Interpreted (London: Oxford University Press, 1964), "Since the Koran is to the faithful the very Word of God, from earliest times orthodox opinion has rigidly maintained that it is untranslatable, a miracle of speech which it would be blasphemous to attempt to imitate" (ix).

77. H.A.R. Gibb, Modern Trends in Islam (Chicago, 1947), 122.

78. Richard Antoun gave a valuable insight into the crucial role of the 'ulama' by warning against "too firm faith in the power of the states and the influence of political elites." See Richard T. Antoun, Muslim Preacher in the Modern World (Princeton, N. J.: 1989), 244. This may perhaps be because of 'the rapport which persists between the 'ulama' and the majority of the Muslim population." See Leonard Binder, Ideological Revolution in the Middle East (New York, 1964), 24.

79. Mr. Eickelman observes that "One pervasive element in Islam as a religious tradition is respect for those aspects of belief and ritual which are considered to be fixed and enduring." See Dale Eickelman, The Middle East: An Anthropological Approach (Englewoods Cliffs, N. J., 1989), 305.

80. From Abu Hurayrah; reported by Jalal al-Din al-Suyuti, al-Jami al-Saghir, vol. 1 (Cairo: 'Abd al-Hamid Ahmad Hanafi, n.d.), 79, on the authority of al-Bukhari and alNasa'i. 